\title{
Reflections
}

\section{The state of Palestinian youth - commentary to Habashi}

\author{
DAVID J. MARSHALL
}

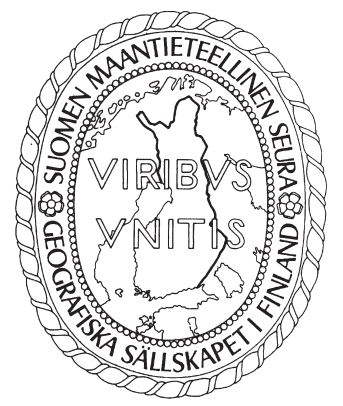

\begin{abstract}
Marshall, D. J. (2019) The state of Palestinian youth - commentary to Habashi. Fennia 197(1) 151-154. https://doi.org/10.11143/fennia.80098

This reflection is a response to Habashi's article "Palestinian children: a transformation of national identity in the Abbas era." It considers the unique scalar and temporal challenges of researching with Palestinian children in the context of a territorially fractured Palestine.
\end{abstract}

Keywords: Palestine, youth, generations, religion, Islam, creative methods

David J. (Sandy) Marshall, Department of History and Geography, Elon University, 100 Campus Drive, Elon, NC 27244, USA. E-mail: dmarshall8elon.edu

As I write this reflection, we are approaching the one-year anniversary of the Great March of Return. These demonstrations started in Gaza on 30 March 2018 (Land Day) as a series of weekly Friday demonstrations demanding the freedom of movement and the right of Palestinian refugees to return to their lands. Although organizers originally planned the protests to culminate on 15 May 2018, the $70^{\text {th }}$ anniversary of the Palestinian Nakba, the weekly protests, which swelled to 30,000 participants at their height, have yet to cease. So far, Israeli soldiers have shot over 6,000 unarmed protestors, killing close to 200 of them (Human Rights Council 2019). Israel faces charges of potential war crimes and appears poised for yet another pre-election escalation. Meanwhile, Hamas faces growing internal turmoil and tensions have spilled over into the West Bank. These tensions come on the heels of unilateral US concessions to Israel, including recognizing sovereignty over the forcefully annexed areas of Jerusalem and the Golan Heights, in contravention of longstanding legal norms and international consensus. Such moves have prompted proclamations that hopes for a peace agreement based on the "two state solution," which have long been on life support, are now completely dead. Even senior Palestinian negotiators like Saeb Erekat are admitting that the only option left for Palestinians is to struggle for one state based on equal rights for all (Landau \& Khoury 2017).

Janette Habashi's research (this issue), as usual, gives us great insight into the views of young people in Palestine, at a time when the peace process has died but a new path forward has yet to be born. In particular, this paper illustrates how the conceptions of Palestinian national identity shift alongside shifts in the national struggle. The period covered in Habashi's (2019) paper, 2007-2011, represents a very turbulent time for internal Palestinian politics following the victory of Hamas in Palestinian legislative elections in 2006. This situation during this period, which I have referred to as the "double occupation" of Palestine (Marshall 2011), has been dominated by the split between a Hamas-governed Gaza and a Fatah-controlled Palestinian Authority (PA) in the West Bank, with ramped up security coordination between the PA and Israel. While reading about how Palestinian children articulate their hopes for national unity and reconciliation within a context of political and territorial divisions, two issues stood out to me, issues that speak specifically to the Palestinian case presented here, but which are also relevant to the study of children's political geography more broadly. Specifically, this paper prompts me to consider some conceptual and methodological concerns related to the issue of spatial scale that continues to vex children's geographies, as well as the issue of temporal scale, typically measured in generations when in studies of children and youth.

URN:NBN:fi:tsv-oa80098 DOI: 10.11143/fennia.80098 a Creative Commons Attribution 4.0 International License. 
Habashi's (2019) paper sets out to examine how Palestinian children read and respond to "local" political events and realities - such as the aforementioned Hamas/Fatah split, repeated Israeli onslaughts against Gaza, continued settlement encroachment, and ongoing imposition of checkpoints and barriers - in terms of their national identity. However, the way that participants blurred scalar boundaries between the local, national, and international spheres in their reactions to these political events and issues is itself interesting. The quotes and empirical vignettes that pepper Habashi's paper pivot between the intimate, immediate and familiar on the one hand, and the broad, distant, and abstract on the other. One participant interweaves the family memories of displacement with a historical narrative of a collective refugee "We," returning from Lebanon, Syria, and Jordan. Similarly, stories vacillate between experiences at local rallies and arrests of local youths by PA police, to discussions of news coverage from Gaza, pronouncements by politicians on Jerusalem, US foreign policy, and the significance of national symbols like the flag and the Dome of the Rock. Even the concrete features of the Palestinian landscape, such as checkpoints and the Apartheid Wall, are discussed as both material, embodied obstacles as well as abstract symbols of oppression and national struggle. The question of how young people form and perform a sense of national identity within the mundane spaces of their everyday lives remains a longstanding methodological challenge within children's geographies, one that is particularly challenging for those of us working in Palestine, where even these mundane spaces are highly politically, emotionally and symbolically charged.

Habashi's study strives to include a geographically representative sample of young people from cities, villages and refugee camps across the West Bank and finds broad conformity in the feelings of national identity across these spaces. On the one hand, this is testament to the strength of Palestinian national identity, which persists despite, and in some ways because of, experiences of ongoing colonization, fragmentation, and exile. On the other hand, with the exception of some examples from Hebron, it is hard to get a feel for a distinct sense of a place or the everyday lives of children who participated in this study. How do young people imagine and perform a sense of national identity and belonging within their surrounding environments, and how might children from villages that abut settlements imagine this belonging differently from children in refugee camps? In short, are their geographic variations in how Palestinians imagine national identity, and how do Palestinians overcome geographic and political divisions to produce a sense of national belonging?

This question clearly relates to the ongoing settler-colonial project in Palestine under Israeli occupation. As the paper rightly emphasizes, Palestine is territorially and demographically fragmented and dispersed. The Oslo Accords divided the West Bank into areas of graduated semi-sovereignty between Areas A, B, and C, and $\mathrm{H} 1$ and $\mathrm{H} 2$ in Hebron (Gordon 2008). Walls surround Jerusalem and Gaza remains a besieged and isolated enclave. Meanwhile, Palestinians living under occupation, within Israel, or in refugee camps, all differ in their abilities to express and enact their national identities and self-determination, or even get counted as Palestinians (Tawil-Souri 2011). How can researchers working within these spaces work together to confront the architecture of occupation and settler colonialism, rather than reproduce its restrictive geographic boundaries? How can researchers overcome various travel and funding restrictions to include children from Gaza, Haifa, Jerusalem, and Shatila Camp in research like this?

One possibility is the use of digital technology. Habashi (2019) has made creative and productive use of journaling in her research with Palestinian young people. How could digital photos snapped by now ubiquitous smart phones help to ground their narratives of national identities more solidly in their local surroundings? How could messaging apps and microblogs, combined with longer form blogs or vlogs, give us a more fine-grained sense of the everyday issues confronting young people in Palestine? Could these technologies be used to enable participants to interact with each other across divisions in virtual focus groups, and what ethical, privacy and security related-issues would that raise? I remain skeptical about the ability of technology to break down barriers, and I think we should always use extreme caution when adopting any geo-locating technology that could be hacked, tracked and surveilled. Nevertheless, the potential benefits of such tools should at least prompt their serious consideration, even among those of us who tend to be technologically unplugged and disinclined.

Alongside the question of how to attend to a specific sense of a place, without obscuring the broader geopolitical context, is a related temporal question of how to attend to the everyday, present 
realities that young people face, while also getting a sense of how they understand their lives within the broader historical passage of time. As this paper indicates, the history of the Palestinian struggle is often narrated in teleological fashion, as the work of successive generations of Palestinians each with their particular role to play. The Jeel an-Nakba (Nakba generation of 1948), struggled to keep alive the memory of historic Palestine, whereas the Jeel ath-Thawra (Generation of Revolution) connected the Palestinian struggle to broader Third World liberation struggles, and the Jeel al-Intifada, sometimes called the Jeel al-Hajar (Intifada Generation or Generation of Stones) directly confronted the Israeli occupation from within (Collins 2004; Peteet 2005). In my research, I have sometimes heard Palestinian adults refer to young people today, with a mix of disdain and hope, as Jeel al-Facebook, and sometimes even as the Jeel al-KitKat (the easily broken "Kit Kat" generation). Parents have told me that the peace process gave them hope for a normal future, so they tried to spoil their children with the normal childhoods they never had. What role do these young people growing up in ayyam Oslo or ayyaam Abbas (the Days of Oslo, or the Days of Abbas) - including new (female) icons of the Palestinian struggle like Ahed Tamimi - see for themselves within (or outside) the struggle, and what form will that struggle take? How do Palestinian girls and boys, and young men and women make sense of the collective memories of struggle in the context of present circumstance and how do they apply nationalist narratives to their own (gendered, situated, embodied) lives?

Mannheim (1952/2012) defines a generation as a group of people who, beyond being born around the same time, share a common significant experience, like war or dramatic social or political change, which gives rise to a common sense of political consciousness. It is tempting to see the Palestinian struggle as weighted down by memory and mired in history, with each successive generation merely experiencing its own round of conflict within a much longer history of repeated violence. Yet, each generation also experiences fresh contact with new configurations of the world that past events have brought into being. Though research in children's geography has thoroughly examined the ways in which the notions of childhood are socially constructed in different ways across time and space, the social construction of generations and intergenerational relations remain ripe for further conceptual and methodological exploration (see Mitchell \& Elwood 2013; Vanderbeck \& Worth 2014; Vanderbeck 2017). Though Habashi's (2017) ecological model of socialization takes into account child/adult mutual socialization even as it disrupts top-down adult-centered models of youth socialization, the emphasis of childhood agency and child-centered methods in children's geographies (combined, perhaps, with the Western conceptions of childhood smuggled into our work), has reproduced a tendency to exclude adults from our research with children. Yet, the moment described in Habashi's (2019) paper in which one of the participants asks their father about his memories of displacement during the 1967 war is a powerful one. In my own recent work with Palestinian refugee children in the West Bank, I have used place-based intergenerational digital storytelling as a method for understanding how young people form a sense of local belonging to the camp even as they articulate a longing for return to a national homeland. This is just one way of exploring how children understand their present surroundings in the context of wider geographic imaginaries and collective memories.

Finally, the last point Habashi's paper has inspired me to reflect on, is an issue that presents a further challenge to the above-mentioned issues of spatial and temporal scale in children's geography, namely, religion. As in her earlier work (Habashi 2008, 2011, 2013, 2017), this article is sensitive to the centrality of religious practices, views and ethics in the construction of self and nation in Palestine. Challenging the narrow interpretations of political Islam, this paper sheds light on how Palestinian children reject crude politicization of religion and its use as a tool for division, instead appealing to the emphasis that Islam places on harmony and compromise as a way of achieving national unity. At the same time, Palestinian children also stress the multi-faith character of Palestinian national identity, expressing solidarity with Christian Palestinians and recognizing the historic presence of Jews in Palestine. Beyond religion's role in national politics, Habashi's (2019) research also underscores religion's role in the Palestinian practices of patience and perseverance in the face of oppression. While we could read this in terms of the mere psychological utility of a religious belief system, these insights gesture at a broader cosmic/temporal worldview through which Palestinian children experience and interpret events around them. At the risk of reproducing problematic framings of the so-called "Palestinian-Israeli conflict" as a primordial religious conflict, rather than a modern political 
struggle over national sovereignty, I think the secular worldview that informs most academic scholarship, has made it difficult for researchers to take seriously how religious perspectives profoundly shape the everyday lives of people in the region. We have a tendency to treat religion in narrow demographic or ideological terms, rather than a lived reality. Habashi's work problematizing top-down models of religious socialization of youth (often read as indoctrination) has been an important step toward rethinking young people's spiritual lives.

Although impasse remains the watchword of politics in Israel/Palestine, it is hard to fight the feeling that Palestine is on the precipice of change. Though about half of all Palestinians still support a twostate solution, most Palestinians feel it is no longer practical or possible in the near term, and most also feel that life has gotten worse since Yasser Arafat signed the Oslo Accords in 1993 (PCPSR 2019). Although nearly 140 UN member states recognize the State of Palestine, that state exercises very limited sovereignty over a very limited territory, and many Palestinians have begun to question whether the Palestinian struggle is a struggle for statehood or for freedom. Perhaps ayyam Oslo and ayyam Abbas are coming to an end. Whatever future directions the Palestinian national movement takes, Habashi's (2019) research with young Palestinians in the West Bank has once again yielded valuable insights into how a new generation of Palestinians views these developments and how they view themselves as Palestinians.

\section{References}

Collins, J. (2004) Occupied by Memory: The Intifada Generation and the Palestinian State of Emergency. New York University Press, New York.

Gordon, D. N. (2008) Israel's Occupation. University of California Press, Berkeley, CA. https://doi. org/10.1525/california/9780520255302.001.0001

Habashi, J. (2008) Palestinian children crafting national identity. Childhood 15(1) 12-29. https://doi. org/10.1177/0907568207086833

Habashi, J. (2011) Children's agency and Islam: unexpected paths to solidarity. Children's Geographies 9(2) 129-144. https://doi.org/10.1080/14733285.2011.562377

Habashi, J. (2013) Children's religious agency: conceptualising Islamic idioms of resistance. Area 45(2) 155-161. https://doi.org/10.1111/j.1475-4762.2012.01126.x

Habashi, J. (2017) Political Socialization of Youth: A Palestinian Case Study. Palgrave Macmillan, New York, NY. https://doi.org/10.1057/978-1-137-47523-7

Habashi, J. (2019) Palestinian children: a transformation of national identity in the Abbas era. Fennia 197(1) 77-93. https://doi.org/10.11143/fennia.71009

Human Rights Council (2019) Report of the independent international commission of inquiry on the protests in the Occupied Palestinian Territory, A/HRC/40/74 25, February 2019. <https://www. ohchr.org/Documents/HRBodies/HRCouncil/CoIOPT/A HRC 40 74.pdf> 28.3.2019.

Landau, N. \& Khoury, J. (2017) 'Two-state solution is over,' top Palestinian diplomat says after Trump's Jerusalem speech'. Haaretz 7.12.2017. <https://www.haaretz.com/middle-east-news/palestinians/. premium-two-state-solution-is-over-top-palestinian-diplomat-says-1.5627973> 28.3.2019.

Marshall, S. (2011) The double-occupation of Palestine. Human Geography 4(1). < https://hugeog.com/ tdoopv2n4d1234/>

Mannheim, K. (1952/2012) Essays on the Sociology of Knowledge. Forgotten Books, London.

Mitchell, K. \& Elwood, S. (2013) Intergenerational mapping and the cultural politics of memory. Space and Polity 17(1) 33-52. https://doi.org/10.1080/13562576.2013.780712

PCPSR (Palestinian Center for Policy and Survey Research) (2019) Public opinion poll no (71). Press release 19.3.2019. <http://www.pcpsr.org/sites/default/files/Pol/\%2071\%20English\%20press\%20 release\%20March\%202019.pdf> 28.3.2019.

Peteet, J. (2005) Landscape of Hope and Despair: Palestinian Refugee Camps. University of Pennsylvania Press, Philadelphia, PA. https://doi.org/10.9783/9780812200317

Tawil-Souri, H. (2011) Colored identity: The politics and materiality of ID cards in Palestine/Israel. Social Text 29(2(107)) 67-97. https://doi.org/10.1215/01642472-1259488

Vanderbeck, R. (2017) Intergenerational geographies in theory and practice. In Skelton, T. \& Aitken, S. (eds.) Establishing Geographies of Children and Young People, 1-23. Springer Singapore (Geographies of Children and Young People), Singapore. https://doi.org/10.1007/978-981-4585-88-0 4-1

Vanderbeck, R. \& Worth, N. (2014) Intergenerational Space. Routledge, New York. 